TAPROBANICA, ISSN 1800-427X. April, 2012. Vol. 04, No. 01: pp. 12-19.

(C) Taprobanica Private Limited, Jl. Kuricang 18 Gd.9 No.47, Ciputat 15412, Tangerang, Indonesia.

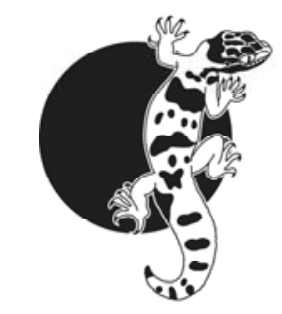

\title{
COVER-DEPENDENCY OF ANURANS IN THE RIVERSTONE, KNUCKLES MOUNTAIN FOREST RANGE, SRI LANKA
}

\author{
Senarathge R. Weerawardhena ${ }^{1,2}$ and Anthony P. Russell ${ }^{1}$ \\ ${ }^{1}$ Department of Biological Sciences, University of Calgary 2500, University Drive NW, Calgary, T2N 1N4, Alberta, \\ Canada; Email: arussell@ucalgary.ca \\ ${ }^{2}$ Department of Zoology, University of Kelaniya, Kelaniya 11600, Sri Lanka; Email: zoosrw@kln.ac.lk
}

\begin{abstract}
The species composition of anurans was studied in the disturbed and undisturbed sub-montane forest habitats in the Riverstone of the Knuckles Mountain Forest Range of Sri Lanka. Twenty one anuran species were encountered. The distribution pattern of collected anuran species was related to the percentage of vegetational cover and they were categorized in relation to dependency on the vegetational cover.
\end{abstract}

Keywords: Abundance, leaf-litter, amphibians, ecology, conservation, Dumbara highlands.

\section{Introduction}

Generally, tea (Camellia sinensis) plantations require about $50 \%$ diffused sunlight for optimal physiological activity (Marby, 1972). Thus, the use of shade trees in tea plantations is an important component. In commercial tea plantations, partial shading is provided by growing tea plants beneath taller trees (i.e. shade trees--planted among tea plants at densities that are not overly competitive with tea plants). For example, canopies of tall (about $10 \mathrm{~m}-15 \mathrm{~m}$ ) trees, such as Albizzia moluccana and Grevillea robusta, and medium (about $3 \mathrm{~m}-5 \mathrm{~m}$ ) shrubs, such as Acacia auriculiformis, Erythrina lithosperma, and Gliricidia sepium, provide partial shade at different times of the day, depending on the direction of incident radiation in relation to tea plantations. The various species of shade trees in tea plantations create different conditions of shade and litter accumulation that, in turn, affect forest regeneration (Zedler, 2007). Rates of litter accumulation vary substantially between different floral compositions and different climatic regions (Zedler, 2007). For example, leaf production in the shrub layer of the tropical forest varies nearly fourfold over the year, and nearly ten-fold in the high canopy layer (Rabenold \& Bromer, 1989). The accumulations of fallen leaves, together with debris of the stages, form a litter-layer that covers the soil surface. Secondary forests are generally categorized as establishing high rates of litter fall relatively quickly, within the first 25 years of secondary succession (Brown \& Lugo, 1990; Ramaksrishnan \& Toky, 1983). Soon after, this plateaus in relation to the litter production rate of the forest (Ewel, 1976). Moreover, formed litter mass is likely to 
reflect development of biomass during secondary succession (Ewel, 1976). The presence of the litter layer can influence the moisture content of the soil surface (Zedler, 2007). Accumulations of litter around tree buttresses and moist spots often harbour many individual anurans, and depending on the moisture regime, anurans that live in forest litter are often highly concentrated (Scott, 1994). Therefore, they are abundant in the litter of tropical forests and the litter-layer could contribute substantially to anuran diversity in these habitats.

Modifications of microclimatic conditions, both above and below ground, also have important influences on floral and faunal distributions and interactions with each other (Stinner \& Stinner, 1989). The presence of macro- and microscopiclitter fauna is important as a foraging microhabitat because most of these species constitute prey items for litter-dwelling anurans (Dodd, 2010; Vitt \& Caldwell, 2001). Moreover, abundance, activity, and feeding behavior of anurans are influenced by temporal variation in the amount and composition of litter, because the saprophagous macrofauna such as earthworms, grasshoppers, insect larvae, isopods and millipedes, processes large amounts of litter and has a tremendous impact on the soil and smaller litter fauna (Anderson, 1988; Hassall et al., 1987).

Frequently encountered terrestrial anurans in the forest litter are bufonids, microhylids and rhacophorids, plus other anurans such as ranids that breed in aquatic habitats but spend most of their adult lives on the forest floor (Dodd, 2010). Some of these anurans, such as Pseudophilautus, are entirely terrestrial and depend on moist litter and cover for their direct developmental mode of reproduction (Dubois, 2004; Meegaskumbura \& Manamendra-Arachchi, 2011; Pethiyagoda \& Manamendra-Arachchi, 1998; Wells, 2007).

Species that prefer open-canopy habitats may gradually be excluded from the close-canopy habitats as canopy cover increases (Wells, 2007). There are a number of reasons for this type of shift of distribution patterns of anurans in relation to the vegetational cover. For example, variances in vegetational cover are likely to be correlated with differences in abundance of prey and predators, light availability, relative humidity (Dietz \& Steinlein, 2002) and moisture content.

The main objective of our research was to study the dependency of anuran species on vegetational cover in tropical forest habitats. To do this, we selected
Sri Lanka as the location of our study because it is considered to be a global hotspot for amphibians (Bossuyt et al., 2004; Meegaskumbura et al., 2002) and provides a rich amphibian fauna (3.9 species per $1,000 \mathrm{~km}^{2}$ ) on which to work. In particular, we selected the KMFR for our study because it is one of the richest regions in Sri Lanka in terms of endemism. Moreover, this region and its anuran fauna, have experienced different anthropogenic influences such as agrochemical application, deforestation, forest dieback, habitat fragmentation, gem mining, illegal and legal agricultural practices, and soil erosion (Amarasinghe \& Karunarathna, 2010), and nowadays still supports areas of virgin forest along with disturbed habitats. We focused on the virgin sub-montane forest leaf-litter and arboreal (i.e. shrub and stem) anuran species (hereafter anurans) in Sri Lanka. We selected anurans because they are closely associated with vegetation, are not highly mobile across broad distances, and are environmentally sensitive animals (Alford \& Richards, 1999; Collins \& Crump, 2009; Collins \& Storfer, 2003; Jepson \& Ladle, 2010; Lannoo, 2005; Wells, 2007).

\section{Materials and Methods}

Study area: The KMFR is situated at $7^{0} 21^{\prime} \mathrm{N} 81^{\circ}$ $45^{\prime} \mathrm{E}$ in the Central Province of Sri Lanka and lies in the Intermediate Zone of Sri Lanka (Fig. 1). The KMFR is oriented at right angles to the two principal wind currents that bring rains (the Southwest and North-east monsoons) to Sri Lanka and it acts as a climatic barrier. The temperature of the KMFR varies across the region, and the mean monthly temperature in the KMFR ranges, between $15^{\circ} \mathrm{C}-25^{\circ} \mathrm{C}$. The wide range of climatic and landscape features exhibited by the KMFR has resulted in a variety of natural vegetation types, ranging from lowland semi-evergreen forests, to sub-montane forests to montane forests (de Rosario, 1958). In the KMFR, the virgin sub-montane forest represents a transitional biological belt between highlands and lowlands. Typical patches of the virgin sub-montane forest are found in Cobert's Gap, Kelabokka, and Riverstone Estate. These lie between $600 \mathrm{~m}-1,300 \mathrm{~m}$ above sea level. Due to strong winds in the virgin sub-montane forest, trees are stunted, much branched and aerodynamically shaped. In relation to competition for light, three strata are present in the virgin sub-montane forest in the KMFR: the herb/shrub layer $(2 \mathrm{~m})$ : the sub canopy $(5 \mathrm{~m})$ : and the canopy $(15 \mathrm{~m})$. Each layer has its own unique plant species (Bambaradeniya \& Ekanayake, 2003). 
Sampling sites: To assess dependency of anurans on vegetational cover in tropical forest habitats, we selected sampling sites in the KMFR on the basis of structural features of the vegetation that differed from one other. We broadly categorized vegetation in the study area into three successional stages: early (ES), middle (MS), and late (LS); each of these stages was represented by ten sampling sites. These served as proxies for time. Currently in production stages (CIP) (tea plantations) are considered as the control stages which exhibit maximum disturbance. The CIP at equivalent distances to the experimental stages selected, were used as a baseline to assess the impact of disturbance on anuran communities compared to those of the virgin sub-montane forest (VF), because this type of forest is considered to be the climax stage. The experimental and reference stages for our study are shown in Table 1 and Fig. 2. Our sampling procedure covers what we postulate to be the composition of the anuran communities before disturbance, the composition of that community after deforestation and the establishment of tea plantations (CIP), and the composition of the anuran communities at three stages (ES, MS, and LS) along the continuum of secondary forest succession, from relatively recently after abandonment to fully established secondary forest structure.

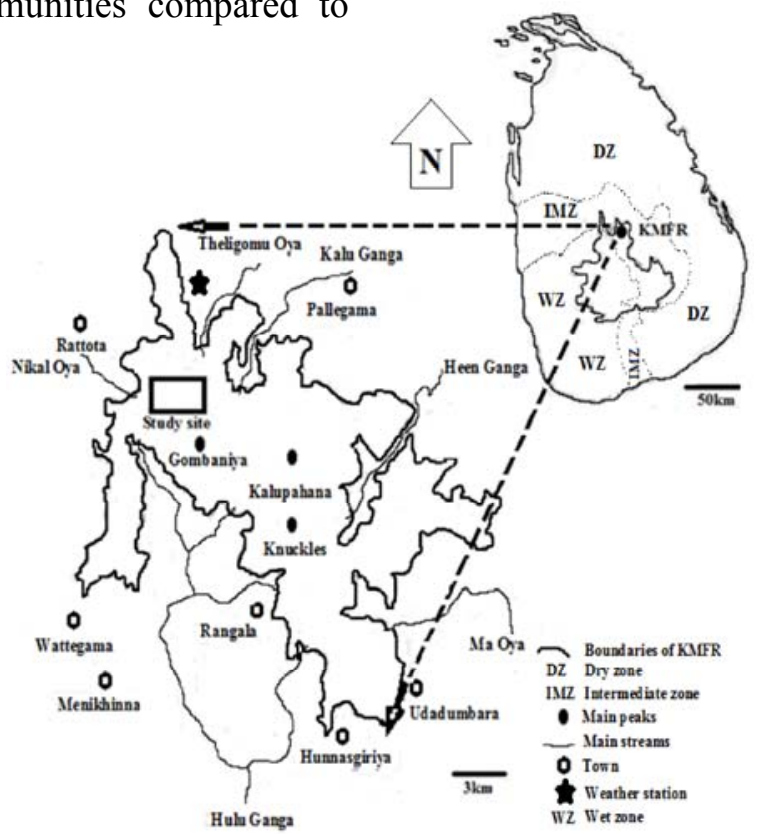

Figure 1: Map depicting the location of the KMFR within Sri Lanka, and the location of the study site (rectangle) within the KMFR (inset).

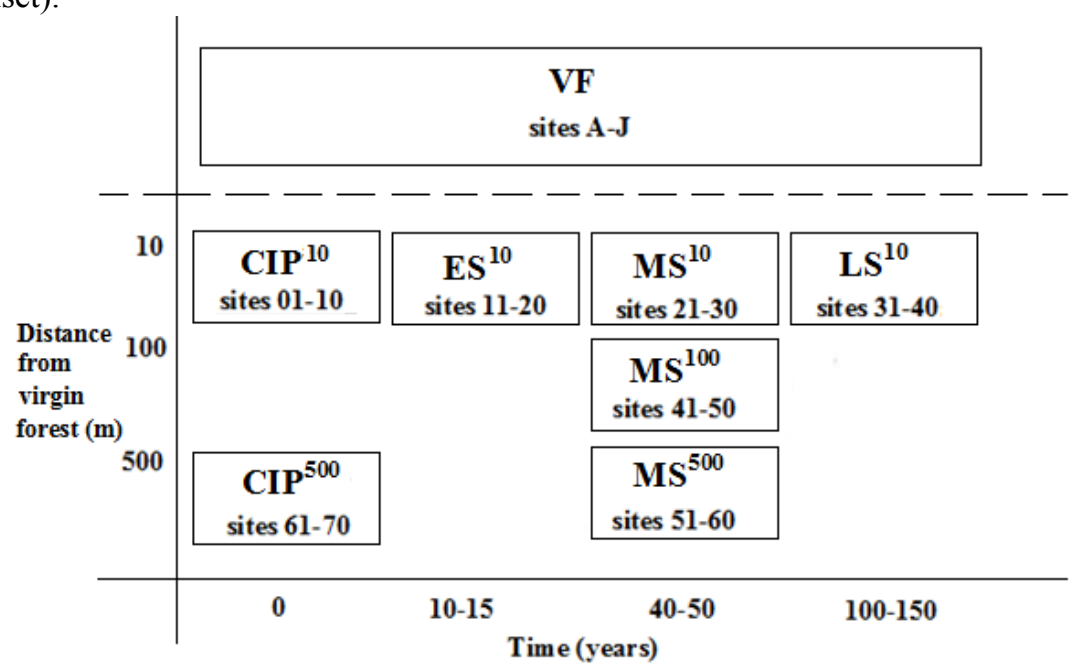

Figure 2: Sampling design for analysis of dynamics of recovery of abandoned tea plantations by anurans in the KMFR, Sri Lanka. The virgin sub-montane forest (VF) represents the "permanent" habitat type to which others are compared. For the succession stages (CIP, ES, MS, LS) the horizontal axis represents a time axis, and the vertical axis a distance axis (with reference to the VF) 
Table 1: Sampling design for examination of anuran communities in the KMFR, Sri Lanka ( $\mathrm{n}=$ no. of sampling sites, * = Sampling site number, see Fig. 2 for representation of sampling site distribution).

\begin{tabular}{|c|c|c|c|}
\hline \multirow{2}{*}{ Vegetation type } & \multicolumn{3}{|c|}{ Distance from virgin sub-montane forest } \\
\hline & $<10 \mathrm{~m}$ & $10-100 \mathrm{~m}$ & $100-500 \mathrm{~m}$ \\
\hline $\begin{array}{l}\text { Tea plantations currently-inproduction (CIP): } \\
\text { Dominated by tea plants, Few grasses and } \\
\text { ferns }\end{array}$ & $\begin{array}{c}\mathrm{n}=10, \\
\text { Site designation } \\
0-10^{*} \\
\text { Acronym } \mathrm{CIP}^{10}\end{array}$ & -- & $\begin{array}{c}\mathrm{n}=10, \\
\text { Site designation } \\
61-70 * \\
\text { Acronym CIP } \\
\end{array}$ \\
\hline $\begin{array}{l}\text { Early successional stage (ES): Dominated by } \\
\text { herbs-chiefly grasses and surviving tea } \\
\text { plants. }\end{array}$ & $\begin{array}{c}\mathrm{n}=10 \\
\text { Site designation } \\
11-20^{*} \\
\text { Acronym ES }{ }^{10}\end{array}$ & -- & -- \\
\hline $\begin{array}{l}\text { Middle succession stage (MS): Dominated by } \\
\text { secondary shrubs that have eliminated pioneer } \\
\text { herbs by shading, Fewer surviving tea plants. }\end{array}$ & $\begin{array}{l}\mathrm{n}=10, \\
\text { Site designation } \\
21-30^{*} \\
\text { Acronym } \mathrm{MS}^{10}\end{array}$ & $\begin{array}{c}\mathrm{n}=10, \\
\text { Site designation } \\
41-50 * \\
\text { Acronym } \mathrm{MS}^{100}\end{array}$ & $\begin{array}{c}\mathrm{n}=10, \\
\text { Site designation } \\
51-60^{*} \\
\text { Acronym } \mathrm{MS}^{500}\end{array}$ \\
\hline $\begin{array}{l}\text { Late succession stage (LS): Dominated by } \\
\text { taller secondary trees with an established } \\
\text { canopy. Forest dense. } 1-2 \text { vertical vegetation } \\
\text { strata. }\end{array}$ & $\begin{array}{c}\mathrm{n}=10 \\
\text { Site designation } \\
31-40^{*} \\
\text { Acronym LS }{ }^{10}\end{array}$ & -- & -- \\
\hline $\begin{array}{l}\text { Virgin sub-montane forest (VF): Dense, } \\
\text { multi-storey, dominated by woody trees. }\end{array}$ & & $\begin{array}{l}\mathrm{n}=10, \\
\text { Site designation A-J* } \\
\text { Acronym VF }\end{array}$ & \\
\hline
\end{tabular}

Period of sampling: Most anurans are more active during wet seasons than during dry seasons, and they are more active during warm periods than during cold periods (Crump, 1994). Therefore, the sampling stages were surveyed during the peak of the wet and dry seasons to gain information about variation of presence and abundance of anurans in relation to seasonal environmental conditions. Accordingly, each stage was sampled five times from April 2008 to April 2009 (Table 2). Field work was conducted from 06:00-10:00 hours (day sampling), and from 18:00-22:00 hours (night sampling). These two periods are considered to be the daily-peak-activity periods of tropical anurans (Duellman \& Lizana, 1994).

Table 2: Sampling periodicity employed in this study (MSL, Monthly sampling; IM, Inter-monsoon; SWM, South-west monsoon; NEM, North-east monsoon)

\begin{tabular}{lcc}
\hline \multicolumn{1}{c}{ Season } & Month & $\begin{array}{c}\text { Sampling } \\
\text { season }\end{array}$ \\
\hline $\begin{array}{l}\text { First IM } \\
\text { (March-April) }\end{array}$ & $\begin{array}{c}\text { April } \\
(2008)\end{array}$ & MSL 1 \\
\hline $\begin{array}{l}\text { SWM } \\
\text { (May-September) }\end{array}$ & $\begin{array}{c}\text { August } \\
(2008)\end{array}$ & MSL 2 \\
\hline $\begin{array}{l}\text { Second IM } \\
\text { (October- November) }\end{array}$ & $\begin{array}{c}\text { November } \\
(2008)\end{array}$ & MSL 3 \\
\hline $\begin{array}{l}\text { NEM } \\
\text { (December- }\end{array}$ & $\begin{array}{c}\text { February } \\
(2009)\end{array}$ & MSL 4 \\
February) & $\begin{array}{c}\text { April } \\
\text { Third IM }\end{array}$ & $\begin{array}{c}\text { MSL 5 (Repeat } \\
\text { of MSL 1) }\end{array}$ \\
\hline
\end{tabular}

Quadrat sampling method: Quadrat sampling is effective for census sampling of anurans, and for closed-canopy forests where species occur in high densities but are difficult to detect because of their secretive habits (Jaeger \& Inger, 1994). We laid quadrats randomly (i.e. independent replicates to avoid pseudoreplication) and employed a $10 \mathrm{~m} \mathrm{x}$ $10 \mathrm{~m}$ sized quadrads, sampling ten quadrats per stage per season (Table 2).

Leaf-litter and arboreal anurans: Four field workers searched for anurans within all microhabitats (i.e., among leaf-litter and among vegetation, inside and under logs, in rock crevices, and under rocks) within each quadrat. One person on each side of the quadrat removed all litter from a $30 \mathrm{~cm}$ broad strip along the outer perimeter of the quadrat to make it easier to spot an escaping animal (Jaeger \& Inger, 1994). Each field worker removed the litter and ground cover from strips inside the quadrat parallel to the boundary twine, and the field-crew worked successive strips from the perimeter toward the centre until the entire area had been sampled. One field worker checked for anurans that were attempting to escape. Individual anurans were collected and identified to species level. To avoid recounting the same individual, release of collected anurans was delayed until the sampling of that quadrat was complete. After identification and cumulative counting, captured anurans were released at their original location of capture. All litter and rocks were replaced. 
Vegetational characteristics: We measured seven structural characteristics of the vegetation to describe the vegetational characters for all quadrats at all sites. These were: percentage of litter cover (proportion of the surface covered by litter); litter depth in $\mathrm{cm}$ (using a meter ruler); percentage of crown cover including canopy and sub-canopy cover (proportion of the surface covered by the aerial parts of the vegetation); density of woody trees (number of woody trees per $100 \mathrm{~m}^{2}$ ); girth at breast height of every tree $(\mathrm{cm})$; and height of vegetation in $\mathrm{m}$ (using an inclinometer).

\section{Results and Discussion}

Our results reveal that the lowest percentage of litter cover and depth occurs in CIP $^{10}$ and CIP $^{500}$ whereas the highest percentage values of litter cover and depth occur were recorded for $\mathrm{LS}^{10}$ and VF (Fig. 3, 4). This is mainly due to human interference involved in pruning, weeding, burning of litter and cleaning (Marby, 1972) of CIP sites. Peterson \& Drewa (2009) showed that higher levels of disturbance in agricultural fields leads to the elimination of litter cover. On the other hand, LS had a lower density of tea plants and a higher percentage of litter cover and depth than did ES and all MS stages (Fig. 3). This is because the amount of ground area covered by litter depends on the canopy cover (Zedler, 2007).

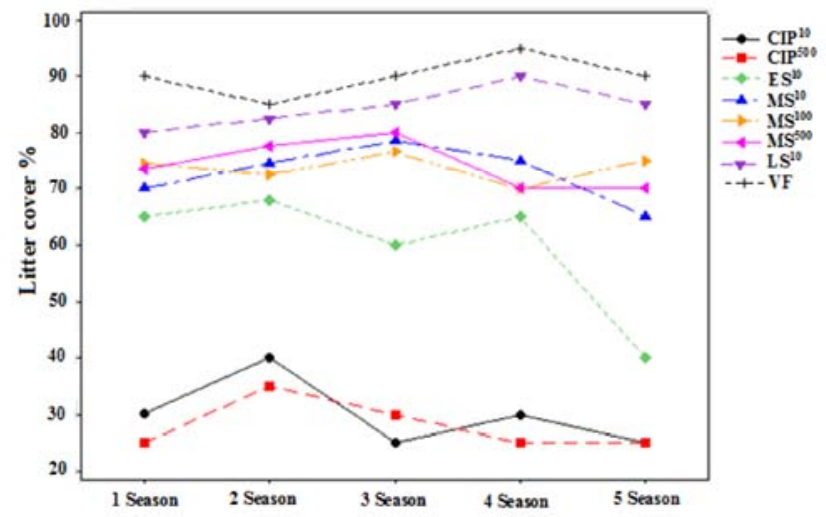

Figure 3: Percentages of litter cover for all stages across the five seasons.

Further, our results show that the areas with the lowest litter cover show the lowest abundance and species richness of anurans. Accumulation of litter increases litter cover, and this could lead to a higher abundance and species diversity of anurans as secondary succession proceeds. The main reason for such a relationship between anuran species and forest-litter is that terrestrial anurans are highly sensitive to the micro-environmental features associated with litter cover (Scott, 1994). We report on our vegetational and micro- environmental findings elsewhere.

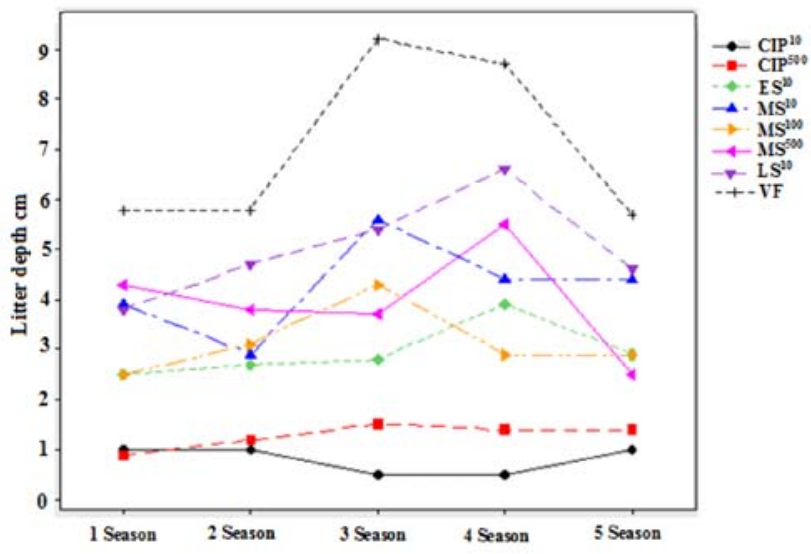

Figure 4: Litter depth $(\mathrm{cm})$ for all stages across the five seasons.

During the course of this study, a total of 237 postmetamorphic anurans, representing 21 species arrayed among the families Bufonidae, Microhylidae, Nyctibatrachidae, Ranidae and Rhacophoridae were collected (Table 3). The relationship between the type of cover and anuran species in the KMFR is listed in Table 3 and it supports the view that most of the collected anurans were closely associated with a particular type of cover. In terms of cover, we broadly categorized encountered anuran species into three groups. They are cover-independent, canopy cover-dependent, and litter cover-dependent species.

Cover-independent or open-canopy anuran species: This group of anuran species lives mostly in open canopy habitats, but does not live in undisturbed forest habitats or in virgin forest habitats. These anuran species are categorized as open canopy species because they do not depend on canopy or litter cover. An example of such an anuran species is Duttaphrynus melanostictus (Table 3). Open canopy species are habitat generalists and are diurnally active (de Silva, 2009).

Canopy cover-dependent or closed-canopy anuran species: Canopy cover is a measure of the area covered by above-ground foliage and stems of plant species, when viewed from above. Greig-Smith, (1983) defined cover as "the proportion of ground occupied by a perpendicular projection on to it of the aerial parts of individuals of the species". Therefore, this constitutes the sum of cover values of multiple species in layered vegetation and thus often totals more than $100 \%$. Wells (2007) pointed out that canopy cover may have a strong influence on the composition of anuran species in tropical 
communities, but this has not been studied comprehensively.

We noted that several anuran species live in closed canopy habitats; accordingly, we categorized them as closed canopy species; examples of these are Pseudophilautus cavirostris; P. mooreorum; P. cf. ocularis and Hylarana temporalis (Table 3). The common feature of all of them is that they are habitat specialists and are restricted to a specific habitat. For example, Pseudophilautus cavirostris; $P$. mooreorum and $P$. cf. ocularis are restricted to closed canopy forests. Hylarana temporalis is also a closed canopy forest species and lives in streams that run through closed canopy forests. Two of the unidentified species of Pseudophilautus, ("red head" and "white eye"), were also collected from closed canopy forest habitats, but due to their low abundance, we are unable to categorize them as canopy cover-dependent species.

Litter cover-dependent anuran species: The litterlayer of the forest floor relates to floral characteristics of the forest. For example, the amount of ground covered by litter depends on the shrub (Dietz \& Steinlein, 2002) and canopy cover.

Heatwole (1961) pointed out that soil moisture and soil temperature affect the processes of decay and mineralization of tropical forest floor litter. Further, he pointed out that the amount and form of organic materials present on the forest floor determine the suitability of the forest floor as a habitat for various types of organisms. The structure of forest litter varies according to the type of leaves or logs that form the litter. For example, litter composed of bent or curved leaves has a greater amount of space available to organisms than that composed of flat leaves (Heatwole, 1961). Moreover, use of the forest litter-layer as a microhabitat depends on the depth or thickness of the layer, the deeper ones providing more space for litter dwelling organisms.

Litter cover-dependent anuran species rely on local conditions of litter accumulation and decay processes (Heatwole, 1961). Generally, litter degradation takes years to occur, and several factors slow down the process. In temperate situations, litter degradation takes about one to 20 years for leaves and needles and up to 100 years for wood, but the decay process is faster in tropical regions (Schulze et al., 2005). Degradation can be significantly reduced by various local factors, such as aerobic conditions, clay content and low $\mathrm{pH}$ (Schulze et al., 2005). Thin leaves probably decay faster than those that are thicker and more heavily cutinized.

Our study revealed that two species of litter cover dwelling anurans, Ramanella obscura and Pseudophilautus ("yellow dorsum") (Table 3). We observed $R$. obscura in virgin forest habitats. It depends on forest litter cover for survival. Although Pseudophilautus (yellow dorsum) was collected among the litter, we are unable to comment on the litter cover dependency of this species, because only one individual was encountered during the field sampling.

Table 3: The type of cover used by anuran species in the KMFR (OC, Live in open canopy; CC, Live in closed canopy; LC, Live under litter cover; $\mathrm{X}=$ Not dependent; $\sqrt{ }=$ Dependent; $\sqrt{ }^{*}=$ Strictly dependent on respective cover).

\begin{tabular}{|c|c|c|c|}
\hline Family \& Species & OC & $\begin{array}{l}\mathbf{C} \\
\mathbf{C}\end{array}$ & LC \\
\hline $\begin{array}{l}\text { Bufonidae } \\
\text { Duttaphrynus melanostictus }\end{array}$ & $\sqrt{ } *$ & $\mathrm{X}$ & $\sqrt{ }$ \\
\hline $\begin{array}{l}\text { Microhylidae } \\
\text { Kaloula taprobanica }\end{array}$ & $\mathrm{X}$ & $\mathrm{X}$ & $\sqrt{ }$ \\
\hline Ramanella obscura & $\mathrm{X}$ & $\mathrm{X}$ & $\sqrt{ } *$ \\
\hline $\begin{array}{l}\text { Nyctibatrachidae } \\
\text { Lankanectes corrugatus }\end{array}$ & $\sqrt{ }$ & $\sqrt{ }$ & $\mathrm{X}$ \\
\hline $\begin{array}{l}\text { Ranidae } \\
\text { Hylarana temporalis }\end{array}$ & $\mathrm{X}$ & $\sqrt{ } *$ & $X$ \\
\hline $\begin{array}{l}\text { Rhacophoridae } \\
\text { Pseudophilautus cavirostris }\end{array}$ & $\mathrm{X}$ & $\sqrt{ } *$ & $X$ \\
\hline P. fergusonianus & $\sqrt{ }$ & $\sqrt{ }$ & $\mathrm{X}$ \\
\hline P. fulvus & $\sqrt{ }$ & $\sqrt{ }$ & $\mathrm{X}$ \\
\hline P. hoffmani & $\mathrm{X}$ & $\sqrt{ }$ & $\mathrm{X}$ \\
\hline P. macropus & $\sqrt{ }$ & $\sqrt{ }$ & $\mathrm{X}$ \\
\hline P. mooreorum & $\mathrm{X}$ & $\sqrt{ } *$ & $\mathrm{X}$ \\
\hline P. cf. ocularis & $\mathrm{X}$ & $\sqrt{*}$ & $\mathrm{X}$ \\
\hline P. sarasinorum & $\sqrt{ }$ & $\sqrt{ }$ & $\mathrm{X}$ \\
\hline P. cf. silus & $\sqrt{ }$ & $\sqrt{ }$ & $\mathrm{X}$ \\
\hline P. steineri & $\sqrt{ }$ & $\sqrt{ }$ & $\sqrt{ }$ \\
\hline P. stuarti & $\mathrm{X}$ & $\sqrt{ }$ & $\sqrt{ }$ \\
\hline Pseudophilautus (red head) & $\mathrm{X}$ & $\sqrt{ } *$ & $\mathrm{X}$ \\
\hline Pseudophilautus (white eye) & $\mathrm{X}$ & $\sqrt{ } *$ & $\mathrm{X}$ \\
\hline Pseudophilautus (yellow dorsum) & $\mathrm{X}$ & $\mathrm{X}$ & $\sqrt{ } *$ \\
\hline Polypedates cruciger & $\sqrt{ }$ & $\sqrt{ }$ & $\mathrm{X}$ \\
\hline Taruga cf. eques & $\sqrt{ }$ & $\sqrt{ }$ & $\mathrm{X}$ \\
\hline
\end{tabular}

Anurans collected from the forest floor use forest litter, cavities under logs, and burrows where relative humidity is high as a result of the accumulation of litter (Zedler, 2007). Such habitat occupancy reduces rates of water loss from the bodies of litter-dwelling anuran species. Occasionally they emerge from their refugia when environmental conditions are favorable, such as at night. This type of adaptive behavioural mechanism 
is useful for avoidance of desiccation and plays an important role in allowing them to survive and thrive in such restricted and particular environmental conditions (Ghalambor et al., 2010; Shoemaker et al., 1992).

Litter-dwelling species are habitat specialists that feed on tiny organisms such as ants, mites, and termites that are scarce in the diets of larger frogs (Wells, 2007). This is true litter-dwelling habitat specialists such as R. obscura.

\section{Conclusion}

Few anuran species are cover independent and live in open habitats, and most are cover-dependent as post-metamorphic individuals. Very few anuran species are entirely dependent on litter cover. The behavioral patterns of anuran species and the type of habitats in the KMFR may have contributed to their cover dependency.

\section{Acknowledgements}

We thank A. Sathurusinghe (Conservator of Forests, Forest Department - Sri Lanka) and S. R. B. Dissanayake (Deputy Director, Department of Wildlife Conservation - Sri Lanka) for granting us permission [permit: R\&E/RES/2-3/UK (Forest Department), WL/3/2/1/7 (Department of Wildlife Conservation)] to work in the KMFR, and for their guidance in this research project. We also thank U. G. Nomantha, N. Weerasinghe and K. Amarasinghe for helping us with field work. This research was in part funded by four Graduate Research Scholarships from the Department of Biological Sciences, University of Calgary and ASG-IUCN/SSC grant to SRW, and a Natural Science \& Engineering Research Council of Canada Discovery Grant, and a University of Calgary Short Term Research Grant to APR.

\section{Literature Cited}

Alford, R. A. and S. J. Richards, 1999. Global amphibian declines: A problem in applied ecology. Annual Review of Ecology and Systematics, 30: 133165.

Amarasinghe, A. A. T. and D. M. S. S. Karunarathna, 2010. Impacts on the amphibians at the Dumbara Highlands, Sri Lanka. Preceedings of the Association for Tropical Biology and Conservation (ATBC), Bali, Indonesia: 8-9.

Anderson, J. M., 1988. Spatiotemporal effects of invertebrates on soil processes. Biological Fertilizer of Soil, 6: 216 - 227.
Bambaradeniya, C. N. B. and S. P. Ekanayake, 2003. A guide to the Biodiversity of Knuckles Forest Region. IUCN, Country Office, Colombo, Sri Lanka: 18.

Bossuyt, F., M. Meegaskumbura, N. Beenaerts, D. J. Gower, R. Pethiyagoda, K. Roelants, A. Mannaert, M. Wilkinson, M. M. Bahir, K. Manamendra-Arachchi, K. P. Ng, C. J. Schneider, O. V. Oomm and M. C. Milinkovitch, 2004. Local endemism within the Western Ghats-Sri Lanka biodiversity hotspot. Science, 306: 479 - 481.

Brown, S. and A. E. Lugo, 1990. Tropical secondary forests. Journal of Tropical Ecology, 6: 1 - 32.

Collins, J. P. and M. L. Crump, 2009 Extinction in our times: Global amphibian decline, Oxford University Press Inc, New Yolk, 10016, USA: 304.

Collins, J. P. and A. Storfer, 2003. Global amphibian declines: Sorting the hypothesis. Diversity and Distribution. Blackwell Publishing Limited, Oxford, United Kingdom. 9: 89 - 98.

Crump, M. L., 1994. Climate and environment. In: Heyer, W. R., M. A. Donnelly, R. W. McDiarmid, L. Hayek, and M. S. Foster (Ed.). Measuring and monitoring biological diversity: Standard methods for amphibians. Smithsonian Institution Press, Washington DC, USA, 42 - 46.

de Rosario, R. A., 1958. The climate and vegetation of the Knuckles region of Ceylon. The Ceylon Forester (N. S), 3(3-4): 207 - 260.

de Silva, A., 2009. Amphibians of Sri Lanka: A photographic guide to common frogs, toads and caecilians. Creative Printers and Designers, Kandy, Sri Lanka: 168.

Dietz, H. and T. Steinlein, 2002. Plant cover: Ecological implications and methodical approaches. In: Ambasht. R. S., and N. K. Ambasht, (Ed.). Modern trends in applied terrestrial ecology. Kluwer Academic/Plenum Publishers, New Yolk, 10013, USA: 184.

Dubois, A., 2004. Development pathways, speciation and supra-specific taxonomy in amphibians: Why dose Sri Lanka has more amphibians? Alytes, 22 (1 \& 2): 19 - 37 .

Dodd, Jr. C. K., 2010. Amphibian ecology and conservation; A handbook of technique. Oxford University Press, Oxford, OX2 6DP, United Kingdom: 464.

Duellman, W. E. and N. Lizana, 1994. Biology of a sit and wait predator: the Leptodactylids frog, Ceratophrys cornuta. Herpetologica, 50 (1): 51 - 64. 
Ewel, J. J., 1976. Litter fall and leaf decomposition in a tropical forest succession in eastern Guatemala. Journal of Ecology, 64: 293 - 308.

Ghalambor, C. K., L. M. Angeloni and S. P. Carroll, 2010. Behavior as phenotypic plasticity, In: Westneat, D. F, and C. W. Fox, (Ed.). Evolutionary Behavioral Ecology. Oxford University Press Inc, New Yolk, 10016, USA: 664.

Greig-Smith, P., 1983. Quantitative Plant Ecology. Third Ed, Oxford, Blackwell Scientific Publication, Oxford, United Kingdom: 374.

Hassall, M., J. G. Turner and M. R. W. Rands, 1987. Effects of terrestrial isopods on the decomposition of different woodland leaf litter. Oecologia, 72: 597 604.

Heatwole, H., 1961. Analysis of the forest floor habitat with a structural classification of the litter or $\mathrm{L}$ layer. Ecological Monographs, 31: 267 - 283.

Jaeger, R. G. and R. F. Inger, 1994. Quadrat sampling. In: Heyer, W. R., M. A. Donnelly, R. W. McDiarmid, L. Hayekand, and M. S. Foster, (Ed.). Measuring and monitoring biological diversity: Standard methods for amphibians. Smithsonian Institution Press, Washington DC, USA, 97 - 102.

Jepson, P. and R. Ladle, 2010. Conservation: A beginner's guide. One-world Publications, Oxford, OX2 7AR, United Kingdom:

Lannoo, M., 2005. Amphibian declines: The conservation status of United States species. University of California, California, USA: 1115.

Marby, H., 1972. Tea in Ceylon: An attempt at a regional and temporal differentiation of the tea growing areas in Ceylon. Franz Steiner Verlar GMBH - Wiesbaden, Germany: 238.

Meegaskumbura, M., F. Bossuyt, R. Pethiyagoda, K. Manamendra-Arachchi, M. M. Bahir, M. C. Milinkovitch and C. J. Schneider, 2002. Sri Lanka: An Amphibian hotspot. Science, 298: 379.

Meegaskumbura, M. and K. Manamendra-Arachchi, 2011. Two new species of shrub frogs (Rhacophoridae; Pseudophilautus) from Sri Lanka. Zootaxa, 2747; 1 - 18.

Pethiyagoda, R. and K. Manamendra-Arachchi, 1998. Evaluating Sri Lanka's amphibian diversity. Occasional Papers of Wildlife Heritage Trust, 2: 1 12.
Peterson, S. M. and P. B. Drewa, 2009. Are vegetation-environmental relationships different between herbaceous and woody groundcover Plants in barrens with shallow soils? Ecoscience, 16 (2): 197 208.

Rabenold, K. N. and W. R. Bromer, 1989. Plant communities as animal habitats: effects of primary resources on the distribution and abundance of animals. In: Abrahamson, W. G. (Ed.). Plant and animal interactions. 291 - 353.

Ramaksrishnan, P. S. and O. Toky, 1983. Secondary succession following slash and burn agriculture in Northeastern India - 2, Nutrient Cycling. Journal of Ecology, 71: 747 - 758.

Schulze, E. D., E. Brek and K. Müller-Hohenstein, 2005. Plant Ecology. Springer Berlin-Heidelberg, Germany: 700 .

Scott, Jr. N. J., 1994. Complete species inventories, In: Heyer, W. R., M. A. Donnelly, R. W. McDiarmid, L., Hayek, and M. S. Foster, (Ed.). Measuring and monitoring biological diversity: Standard methods for amphibians. Smithsonian Institution Press, Washington DC, USA, 76 - 84.

Shoemaker, V. H., S. S. Hillman, S. D. Hillyard, D. C. Jackson, L. L. McClanahan, Jr, P. C. Withers and M. L. Wygoda, 1992. Exchange of water, ions, and respiratory gases in terrestrial amphibians. In: Feder, M. E., and W. W. Burggren (Ed.). Environmental Physiology of the Amphibians. University of Chicago Press, Chicago, USA, 125 - 150.

Stinner, B. R. and D. H. Stinner, 1989. Plant-animal interactions in agricultural ecosystems, In: Abrahamson, W. G. (Ed.). Plant and animal interactions. 355 - 393.

Vitt, L. J. and J. P. Caldwell, 2001. Resource utilization and guild structure of small vertebrates in the Amazon forest leaf litter. Journal of Zoology, 234: $463-476$.

Wells, K. D., 2007. The ecology and behavior of amphibians. The University of Chicago Press, Chicago, Chicago, USA: 1400.

Zedler, P. H., 2007. Fire effects on grasslands. In: Johnson, E. A., and K. Miyanishi, (Ed.). Plant Distribution Ecology: the process and the response. Elsevier Inc, MA 01803, USA, 397 - 439. 